\title{
ZONASI EKOWISATA KAWASAN KONSERVASI PESISIR DI KECAMATAN KATINGAN KUALA, KABUPATEN KATINGAN, PROVINSI KALIMANTAN TENGAH MELALUI PENDEKATAN EKOLOGI BENTANG LAHAN
}

\author{
CAKRA BIRAWA \& RADEN MAS SUKARNA*
}

Jurusan Kehutanan Fakultas Pertanian Universitas Palangka Raya

Jl. H. Timang Palangka Raya Kalimantan Tengah 73111

*Email: radenmassukarna@gmailcom

\begin{abstract}
Marine and coastal areas as well as their natural resources have strategic effects towards the economic development of Indonesia because they are reliable to be one of the pillars of the national economy. Utilization and management of coastal areas either conducted by the community or local government have not reflect the conservation and sustainable aspects. To support these conditions, it is necessary to develop ecotourism zone, which is able to improve the local economies. This research aimed to study ecotourism zone of the coastal conservation area in Katingan Kuala Sub-district, Central Kalimantan Province through landscape ecology approach. The results showed that the total area of Katingan Kuala Sub-district, which is $1,440 \mathrm{~km}^{2}$, could be categorized into four sub-zones, i.e. ecotourism zone is $\pm 15.83 \%$, buffer zone is $\pm 31.30 \%$, core zone for conservation and rehabilitation is $\pm 29.55 \%$, and production and economic zone is $\pm 23.31 \%$. It was concluded that ecotourism development in these coastal areas should be in harmony with the conservation, protection, and preservation of the environment as a whole.
\end{abstract}

Keywords: ecotourism zonation, landscape ecology, coastal conservation, sustainable development, Katingan Kuala

\section{INTISARI}

Wilayah laut dan pesisir beserta sumberdaya alamnya memiliki pengaruh strategis terhadap pengembangan ekonomi Indonesia karena dapat diandalkan sebagai salah satu pilar ekonomi nasional. Pemanfatan dan pengelolaan kawasan pesisir yang dilakukan oleh masyarakat maupun pemerintah daerah belum mencerminkan aspek-aspek kelestarian dan keberkelanjutan. Untuk mendukung hal tersebut, perlu dikembangkan zona ekowisata yang mampu meningkatkan ekonomi masyarakat lokal. Penelitian ini bertujuan untuk mempelajari zona ekowisata kawasan konservasi pesisir di Kecamatan Katingan Kuala Kabupaten Katingan, Provinsi Kalimantan Tengah melalui pendekatan ekologi bentang lahan. Hasil penelitian menunjukkan bahwa dari seluruh luas wilayah Kecamatan Katingan Kuala $\left(1.440 \mathrm{~km}^{2}\right)$ dapat dikategorikan dalam empat sub zona, yaitu zona ekowisata $\pm 15,83 \%$, zona penyangga $\pm 31,30 \%$, zona inti untuk konservasi dan rehabilitasi $\pm 29,55 \%$, dan zona produksi dan ekonomi $\pm 23,31 \%$. Disimpulkan bahwa kegiatan pengembangan ekowisata di wilayah pesisir ini harus serasi dan selaras dengan upaya konservasi, perlindungan, dan pelestarian lingkungan hidup secara menyeluruh.

Kata kunci: zonasi ekowisata, ekologi bentang lahan, konservasi pesisir, pembangunan keberlanjutan, Katingan Kuala. 


\section{PENDAHULUAN}

Ekosistem pesisir merupakan ekosistem yang dinamis dan mempunyai kekayaan habitat yang beragam, baik di darat maupun di laut yang saling berinteraksi satu dengan lainnya. Kawasan pesisir merupakan ekosistem yang paling mudah terkena dampak pembangunan baik secara langsung maupun tidak langsung (Dahuri et al., 1996). Wilayah pesisir merupakan wilayah yang unik karena merupakan percampuran antara darat dan perairan yang dikenal sebagai daerah ekoton. Nybaken (1989) menjelaskan bahwa kawasan pesisir merupakan salah satu kawasan yang memiliki produktivitas hayati yang tinggi. Ekosistem alami yang terdapat di wilayah pesisir antara lain adalah terumbu karang (coral reefs), hutan mangrove, padang lamun (sea grass), pantai berpasir (sandy beach), estuaria, laguna, dan delta. Ekosistem buatan antara lain berupa: tambak, sawah pasang surut, kawasan pariwisata, kawasan industri, kawasan agroindustri dan kawasan pemukiman (Pemerintah Daerah Propinsi Kalimantan Tengah, 2003).

Indonesia sebagai negara kepulauan berkembang menjadi kawasan dengan pertumbuhan yang pesat, mengingat kawasan pesisir dapat menyediakan ruang dengan aksesibilitas tinggi dan relatif murah dibandingkan dengan ruang daratan di atasnya. Hampir 60 \% jumlah penduduk di kota-kota besar, seperti Jakarta, Surabaya, Semarang, Medan, dan Makasar menyebar ke daerah pesisir (Dahuri et al, 1996). Dalam kaitan dengan kemudahan akses dan hubungan antar pulau dan antar wilayah itulah sebagian besar kota-kota di Indonesia berada di kawasan pesisir. Berdasarkan fakta tersebut, dapat dikatakan bahwa pengelolaan kawasan pesisir merupakan komponen penting yang perlu diperhatikan dalam menunjang pembangunan di Indonesia
Pemanfaatan dan pengelolaan daerah pesisir yang dilakukan oleh Pemerintah Daerah maupun masyarakat sebagian belum memenuhi ketentuan pemanfaatan sumberdaya alam secara lestari dan berkelanjutan. Undang Undang Nomor 27 Tahun 2007 (Undang Undang Nomor 1 Tahun 2014) tentang perubahan pasal 7 ayat 3 yang mengamanatkan Pemerintah Daerah wajib menyusun semua dokumen rencana (Rencana Strategis Wilayah Pesisir dan Pulau-Pulau Kecil, Rencana Zonasi Wilayah Pesisir dan PulauPulau Kecil, Rencana Pengelolaan Wilayah Pesisir dan Pulau-Pulau Kecil dan Rencana Aksi Pengelolaan Wilayah Pesisir and Pulau-Pulau Kecil). Tanggung jawab pemerintah adalah mengatur pengalokasian ruang atau zona wilayah pesisir untuk dapat digunakan dalam memaksimalkan pengelolaan dan pemanfaatan wilayah pesisir.

Pertumbuhan penduduk yang tinggi dan pesatnya kegiatan pembangunan di kawasan pesisir seperti pemukiman, perikanan, pelabuhan, dan lain-lain menyebabkan tekanan ekologis terhadap ekosistem dan sumberdaya kawasan pesisir semakin meningkat pula. Tekanan ini tentunya dapat mengancam keberadaan dan kelangsungan ekosistem dan sumberdaya pesisir baik secara langsung maupun tidak langsung. Salah satu tahapan penting yang diperlukan dalam mengantisipasi permasalahan ini adalah menyusun rencana pengelolaan ekosistem dan sumberdaya kawasan pesisir secara komprehensif dan terpadu melalui kajian zonasi ekologi bentang lahan terhadap seluruh potensi wilayah pesisir. Kajian dan penyusunan zonasi pesisir mempunyai arti penting bagi kehidupan di laut dan mendukung sebagian besar sumberdaya hayati laut. Lahan basah, laguna, padang lamun, terumbu karang, dan teluk-teluk dangkal yang merupakan daerah pertumbuhan atau habitat bagi kebanyakan jenisjenis fauna pesisir dan banyak spesies laut lainnya. 
Suparno (2009) menjelaskan bahwa tujuan penyusunan rencana zonasi adalah untuk membagi wilayah pesisir dalam zona-zona yang sesuai dengan peruntukan dan kegiatan yang saling mendukung (compatible) serta memisahkannya dari kegiatan yang saling bertentangan (incompatible). Penentuan zona difokuskan berdasarkan kegiatan utama dan prioritas pemanfaatan sumberdaya pesisir guna mempermudahkan pengendalian dan pemanfaatan.

Kecamatan Katingan Kuala, Kabupaten Katingan, Provinsi Kalimantan Tengah memiliki kawasan pesisir yang khas dan potensial untuk dimanfaatkan dan dikelola dengan kaidah konservasi bagi peningkatan kesejahteraan masyarakat secara berkelanjutan. Tekanan yang kuat terhadap kawasan pesisir wilayah ini harus dikaji dan diteliti secara komprehensif sehingga diperoleh data dan informasi yang akurat dan dapat dikembangkan untuk menentukan skala prioritas pembangunan ekonomi yang ramah lingkungan seperti jasa ekowisata. Awal tahun 1990, The International Ecotourism Society (TIES) mendefinisikan ekowisata sebagai perjalanan bertanggungjawab ke wilayah-wilayah alami dengan menjaga kelestarian lingkungan dan meningkatkan kesejahteraan penduduk setempat. Priono (2012) menjelaskan bahwa secara konseptual, ekowisata merupakan suatu konsep pengembangan pariwisata berkelanjutan yang bertujuan untuk mendukung upaya-upaya pelestarian lingkungan (alam dan budaya) dan meningkatkan partisipasi masyarakat dalam pengelolaan sehingga memberi manfaat ekonomi kepada masyarakat setempat.

Permasalahan mendasar yang dihadapi adalah bahwa potensi ekowisata pada kawasan pesisir Kecamatan Katingan Kuala belum mampu dikelola dan dimanfaatkan secara maksimal sebagai peluang oleh pemerintah daerah maupun oleh masyarakat setempat. Pengelolaan potensi ekowisata dapat memberikan peluang kepada masyarakat lokal dalam memperoleh tambahan ataupun peningkatan pendapatan diperoleh melalui menjual cenderamata, menyediakan jasa angkutan, dan sebagainya. Upaya untuk mendukung ekowisata wilayah pesisir tersebut adalah dengan melakukan zonasi ekowisata yang terukur dan representatif melalui pendekatan ekologi bentang lahan. Manfaat yang diharapkan dari penelitian ini adalah dihasilkannya zona prioritas untuk membuat rencana strategis pengembangan daerah ekowisata yang ekonomis dan berkelanjutan.

\section{BAHAN DAN METODE}

Metode yang digunakan dalam penelitian ini dilakukan melalui tiga pendekatan, yaitu (1) penyusunan rencana zonasi dengan mempertimbangkan kebijakan pembangunan yang telah ditetapkan oleh Pemerintah Pusat dan Daerah, kepentingan masyarakat dan hak-hak ulayat, serta kepentingan yang bersifat khusus, (2) pendekatan bio-ekoregion dimana ekosistem pesisir dibentuk oleh sub-ekosistem yang saling terkait satu sama lainnya. Oleh sebab itu, kombinasi penggunaan data biogeofisik yang mengambarkan kondisi bioekoregion merupakan persyaratan yang dibutuhkan dalam menetapkan zona-zona yang akan dipilih, dan (3) pengumpulan data dan informasi yang dapat diperoleh dari persepsi masyarakat setempat, terutama hal yang berkaitan dengan pemanfaatan sumberdaya pesisir dari dulu sampai saat ini. Kegiatan analisis data dilakukan sebagai berikut :

1. Melakukan analisis citra komposit (False Color Composite) terhadap Citra Landsat 5 untuk menentukan variasi penutupan lahan pada lokasi penelitian. 
2. Melakukan analisis spasial terhadap data digital sistem lahan untuk menentukan zonasi tipe lahan pada lokasi penelitian

3. Melakukan analisis ekologi bentang lahan melalui sistem informasi geografis (SIG) terhadap seluruh satuan lahan menggunakan pendekatan nilai kecocokan (matching) untuk mendapatkan zonasi ekowisata wilayah konservasi pesisir.

4. Berdasarkan zonasi tersebut, dilakukan survei ke lapangan untuk melakukan validasi lokasi terhadap kesesuaian zonasi ekowisata wilayah pesisir dan diskusi baik dengan masyarakat maupun Pemerintah Daerah setempat.

\section{Lokasi Penelitian}

Kajian pengembangan arahan zona wisata dan jasa lingkungan dilaksanakan di wilayah Kecamatan Katingan Kuala, Kabupaten Katingan, Provinsi Kalimantan Tengah yang secara geografis terletak antara $113^{\circ} 10^{\prime}-113^{\circ} 40^{\prime}$ BT dan $2^{\circ} 50^{\prime}-3^{\circ} 15^{\prime}$ LS, dengan luas wilayah $1.440 \mathrm{~km}^{2}$ (Gambar 1). Kawasan Rencana Zonasi mencakup semua wilayah Kecamatan Katingan Kuala di pesisir. Secara spesifik, batas wilayah daratan untuk rencana zonasi ditetapkan sama dengan batas administrasi kecamatan, dan batas ke arah laut sampai 4 mil laut pada tingkat pemerintahan Kabupaten Katingan.

\section{Analisis Citra Komposit}

Analisis citra komposit dilakukan terhadap Citra Landsat 5 Path/Row 118/062 Tahun 2010 melalui kombinasi band 543 menggunakan supervised classification dan filtering. Hasil analisis citra tersebut digunakan sebagai acuan untuk menentukan penutupan lahan wilayah penelitian.

\section{Analisis Spasial Tipe Lahan}

Analisis tipe lahan menggunakan data digital sistem lahan wilayah Kota Palangka Raya dari RePProT (1987). Klasifikasi tipe lahan pada wilayah penelitian menggunakan pendekatan kedalaman gambut dan bentukan sedimen yaitu tipe lahan rawa bergambut dalam (deep peat swamp), tipe lahan rawa bergambut tipis (shallow peat swamp), tipe lahan dataran sungai, dan estuari (coalescent estuarine/ riverine plans), dan daerah pantai (inter-tidal mudflats).

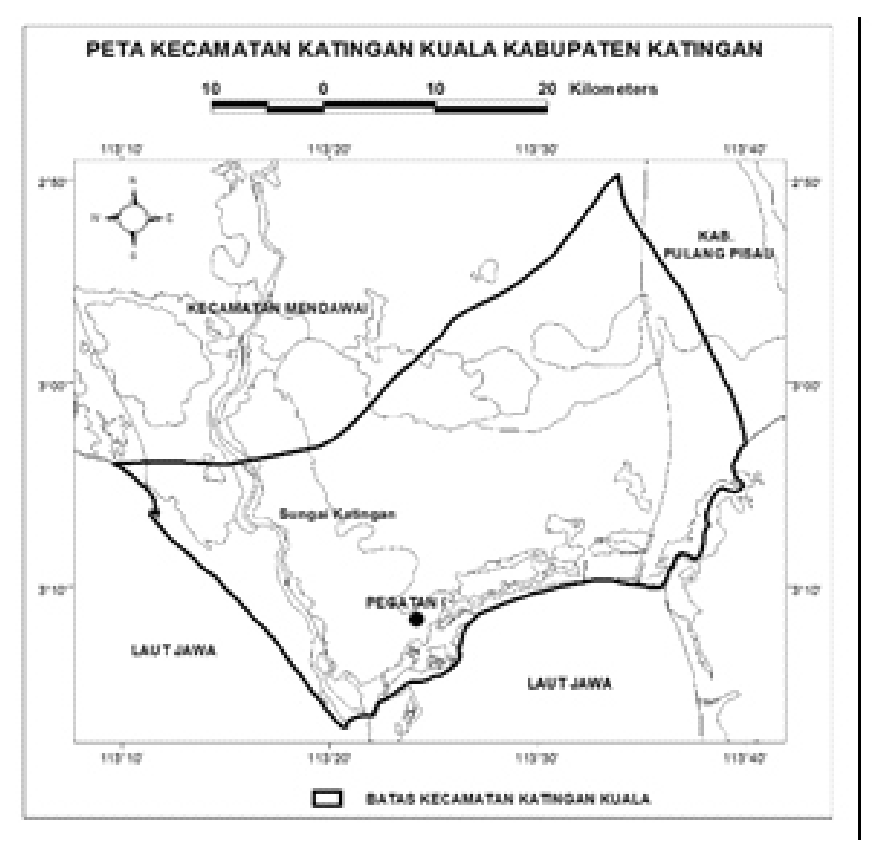

Gambar 1. Peta lokasi penelitian di Kecamatan Katingan Kuala Kabupaten Katingan Provinsi Kalimantan Tengah 


\section{Analisis Ekologi Bentang Lahan}

Analisis ekologi bentang lahan dalam penelitian ini dilakukan dengan mengintegrasikan karakteristik biofisik wilayah pesisir yaitu tipe lahan, tanah, geologi, dan keanekaragaman flora dengan mempertimbangkan pembagian suatu wilayah ke dalam karakteristik yang relatif homogen (Young et al., 1993). Metode analisis ekologi bentang lahan mengacu pada Zonneveld (2001) yang memberikan dasar deskripsi sebagai berikut: (1) Ecotope merupakan unit lahan terkecil yang secara keseluruhan memiliki paling tidak satu atribut lahan (iklim, vegetasi, tanah, batuan, air dan lain-lain), (2) Land facet merupakan kombinasi bentuk suatu hubungan keruangan ecotope dengan sifat-sifat yang jelas dan memiliki paling tidak satu atribut bentuk lahan, (3) Land system merupakan kombinasi land facet yang membentuk unit kesesuaian pada skala tinjau, (4) Main landscape merupakan suatu kombinasi dari land system di dalam satu wilayah geografis (disebut juga dengan istilah macrochore). Metode ini juga didasari oleh deskripsi bentang lahan oleh Vink (1983), Forman dan Gordon (1986), dan Farina (1998).

Pembagian zona dilakukan berdasarkan Peraturan Menteri No.17 Tahun 2008 tentang Kawasan Konservasi di Wilayah Pesisir dan Pulau-Pulau Kecil pasal 31 ayat 2 yang membagi sistem zonasi ke dalam tiga yaitu zona inti, zona pemanfaatan terbatas, dan zona lainnya yang sesuai dengan peruntukan kawasan. Pertimbangan lain untuk menentukan zona ekowisata wilayah pesisir pada lokasi penelitian adalah: (1) sebaran tipe ekosistem secara geografis melalui peta dasar maupun peta tematik, (2) kondisi demografi wilayah penelitian, (3) keunikan spesies yang dominan, spesies penting (langka/endemik/ dilindungi), dan (4) upaya pelestarian dan pemanfaatan kawasan konservasi pesisir laut yang saat ini telah dilakukan.

\section{HASIL DAN PEMBAHASAN}

\section{Demografi Wilayah Pesisir}

Data statistik tahun 2014 menunjukkan bahwa jumlah penduduk di Kecamatan Katingan Kuala tercatat sebesar 20.291 jiwa dengan rincian 10.539 jiwa penduduk laki-laki dan 9.752 jiwa penduduk perempuan, dengan tingkat kepadatan penduduk sebesar 14,09 jiwa per kilometer persegi. Berdasarkan data statistik tahun 2013, jumlah penduduk miskin di Kabupaten Katingan adalah 6,55 \% dengan laju pertumbuhan penduduk 1,56\% tahun 2013, dan $1,65 \%$ tahun 2014. Indeks pembangunan manusia (IPM) di Kabupaten Katingan tahun 2013 adalah 73,83 dengan angka harapan hidup 67,72. Mata pencaharian utama masyarakat di Kecamatan Katingan Kuala lebih dari $70 \%$ adalah petani. Berdasarkan kondisi demografi seperti ini akan menyebabkan besarnya tekanan terhadap kawasan konservasi baik dari masyarakat setempat maupun investasi dari luar. Untuk mengurangi besarnya tekanan terhadap kawasan konservasi pesisir sebaiknya dapat dikembangkan wilayah ekonomi yang ramah lingkungan seperti ekowisata. Suparno (2009) menjelaskan bahwa rencana zonasi pesisir dan laut akan menetapkan suatu jaringan/kisi-kisi spasial di atas lingkungan pesisir dan laut. Rencana ini memisahkan pemanfaatan sumberdaya yang saling bertentangan dan menentukan yang mana kegiatan-kegiatan yang dilarang dan diijinkan ditunjukkan untuk setiap zona peruntukan.

Priono (2012) menjelaskan bahwa secara konseptual, ekowisata merupakan suatu konsep pengembangan pariwisata berkelanjutan yang bertujuan untuk mendukung upaya-upaya pelestarian lingkungan (alam dan budaya) dan meningkatkan 
partisipasi masyarakat dalam pengelolaan sehingga memberi manfaat ekonomi kepada masyarakat setempat. Prinsip dasarnya harus mencakup aspek konservasi, partisipasi masyarakat, ekonomi, edukasi, dan wisata. Pengembangan ekowisata harus mampu memelihara, melindungi, dan/atau berkontribusi untuk memperbaiki sumberdaya alam. Memiliki kepedulian, tanggung jawab, dan komitmen terhadap pelestarian lingkungan alam dan budaya, melaksanakan kaidah-kaidah usaha yang bertanggung jawab, dan ekonomi berkelanjutan. Peka dan menghormati nilai-nilai sosial budaya dan tradisi keagamaan masyarakat setempat.

Pengembangan harus didasarkan atas musyawarah dan persetujuan masyarakat setempat serta peka dan menghormati nilai-nilai sosial budaya dan tradisi keagamaan yang dianut masyarakat setempat di sekitar kawasan. Pengembangan ekowisata harus mampu memberikan manfaat untuk masyarakat setempat dan menjadi penggerak pembangunan ekonomi di wilayahnya untuk memastikan bahwa daerah yang masih alami dapat mengembangkan pembangunan yang berimbang (balance development) antara kebutuhan pelestarian lingkungan dan kepentingan semua pihak. Pengembangan ekowisata harus mengandung unsur pendidikan untuk mengubah sikap atau perilaku seseorang menjadi memiliki kepedulian, tanggung jawab, dan komitmen terhadap pelestarian lingkungan. Pengembangan ekowisata juga harus meningkatkan kesadaran dan apresiasi terhadap alam, nilai-nilai peninggalan sejarah, dan budaya, serta memberikan nilai tambah dan pengetahuan bagi pengunjung, masyarakat, dan para pihak yang terkait. Pengembangan ekowisata harus dapat memberikan kepuasan pengalaman kepada pengunjung untuk memastikan usaha ekowisata dapat berkelanjutan. Selain itu, pengembangan ekowisata juga harus mampu menciptakan rasa aman, nyaman, dan memberikan kepuasan serta menambah pengalaman bagi pengunjung.

\section{Jenis Tanah Wilayah Pesisir}

Hasil analisis tanah pada lokasi contoh penelitian disajikan pada Tabel 1 menunjukkan bahwa tanah yang ada di wilayah lokasi studi cukup baik untuk pengembangan usaha antara lain usaha pertambakan dan pertanian (sawah pasang surut) berdasarkan tekstur dan strukur dari tanahnya terutama untuk areal pengembangan daerah di kawasan konservasi di daerah pesisir. Tekstur tanah akan berpengaruh pada konstruksi. Semakin tinggi kadar liat dan semakin sedikit kadar pasir akan semakin stabil dan semakin kedap air. Darmawijaya (1997) menjelaskan bahwa produktivitas tanah seperti alluvial rendah sampai tinggi cukup baik digunakan untuk kegiatan pertanian dan perikanan.

Tabel 1 menunjukkan bahwa tekstur tanah (\%) memiliki: a) kandungan pasir 0,86-32,75\%; dan b)

Tabel 1. Hasil analisis tanah pada lokasi penelitian

\begin{tabular}{|c|c|c|c|c|c|c|c|c|c|c|c|c|}
\hline \multirow{2}{*}{$\begin{array}{l}\text { Lokasi } \\
\text { Contoh }\end{array}$} & \multicolumn{3}{|c|}{ Tekstur (\%) } & \multirow{2}{*}{$\begin{array}{c}\mathrm{C} \\
\\
-0\end{array}$} & \multirow{2}{*}{$\begin{array}{ll} & \mathrm{N} \\
\% & - \\
\end{array}$} & \multirow{2}{*}{$\begin{array}{c}\text { P-Bray } \\
\text { Ppm }\end{array}$} & \multirow{2}{*}{$\begin{array}{c}\mathrm{pH} \\
\mathrm{H}_{2} \mathrm{O}\end{array}$} & \multirow{2}{*}{ Ca-dd } & \multirow[t]{2}{*}{ Mg-dd } & Na-dd & \multirow[t]{2}{*}{ K-dd } & \multirow[t]{2}{*}{ KTK } \\
\hline & & & & & & & & & & & & \\
\hline & & 48 & & & & & & & & & & 0,9 \\
\hline & & & & & & & & & & & & 9,2 \\
\hline & & & & & & & & & & & & , \\
\hline & & & & & & & & & & & , 20 & 59,8 \\
\hline $\lg 2$ & 18,17 & 42,97 & 8,86 & 3,18 & 0,44 & 0,35 & 5,12 & 4,64 & 0,60 & 0,22 & 0,34 & 30,3 \\
\hline
\end{tabular}

Sumber: hasil analisis laboratorium tanah Universitas Palangkaraya 2014 
kandungan debu 41,01-48,32\%; serta c) kandungan liat 26,24-52,33 \%. Kelas tekstur: a) Kawasan Pulau Burung lempung liat berdebu, b) Katingan I lempung, c) Kawasan Pulau Damar liat berdebu, d) Katingan II liat berdebu, dan e) Pulau Burung Kiri lempung liat berdebu. Struktur remah dan masif. Kandungan C antara 3,18-12,47 \%; kandungan N antara 0,21-0,44 \%; kandungan P-bray antara 8,98-28,54 ppm; kandungan $\mathrm{pH} \mathrm{H}_{2} \mathrm{O}$ tanah berkisar antara 4,4-5,47; kandungan Ca-dd berkisar antara 0,55-9,34 me/100 g; kandungan Mg-dd berkisar antara 0,50-0,94 me/100 g; kandungan Na-dd berkisar antara 0,01-1,64 me/100 g; kandungan K-dd berkisar antara 0,15-0,87 me/100 g; dan kandungan KTK berkisar antara 29,27-59,85 me/100 g.

Tanah merupakan salah satu faktor yang dapat mempengaruhi produktivitas tambak, sebab tanah mempunyai kemampuan untuk menyerap atau melepaskan zat hara tanaman yang dibutuhkan oleh phytoplankton atau vegetasi air lainnya yang hidup di dalam tambak. Di samping itu, tanah juga merupakan komponen utama dalam pembuatan petakan tambak, pematang, saluran air, dan pintu air serta mempunyai peranan penting dalam menentukan kualitas air. Fungsi tanah yang utama bagi tambak adalah menyediakan unsur hara yang sangat dibutuhkan untuk pertumbuhan makanan alami udang windu dan ikan bandeng di tambak, menjadi media pertumbuhan makanan alami berupa klekap atau organisme makanan lainnya untuk menahan air.

Hasil penelitian menunjukkan bahwa sebagian besar wilayah Kecamatan Katingan Kuala merupakan daerah datar dimana sekitar $89 \%$ merupakan wilayah dengan kemiringan lereng 0-2 \%. Jenis tanah di Kecamatan Katingan Kuala terdiri atas 5 (lima) jenis dengan luas masing-masing:

a. tanah jenis aluvial marine seluas 30.120 ha,

b. tanah jenis aluvial gleihumus seluas 256.140 ha, c. tanah jenis organosol seluas 256.140 ha,

d. tanah jenis regosol seluas 10.090 ha,

e. tanah jenis litosol seluas 5.840 ha,

f. tanah jenis podsolik merah kuning seluas 12.460 ha.

Data tersebut di atas menunjukkan bahwa sebagian besar wilayah Kecamatan Katingan Kuala adalah tanah organosol dan aluvial gleihumus yang mencapai sekitar $80 \%$. Karena sebagian besar jenis tanah di Kecamatan Katingan Kuala berjenis gambut (organosol) yang tidak memiliki tubuh tanah, maka hanya sekitar $20 \%$ sisanya yang dapat diketahui kedalaman efektif tanahnya. Dari sekitar $20 \%$ yang memiliki tubuh tanah tersebut, maka sebagian besar mempunyai kedalaman efektif di atas $90 \mathrm{~cm}$ mencapai luas 51.220 ha dan kedalaman efektif antara 30-60 cm mencapai luas 2.730 ha. Berdasarkan kondisi ini, Kecamatan Katingan Kuala mempunyai potensi cukup besar untuk pengembangan tanaman perkebunan yang pada umumnya memiliki akar yang relatif panjang. Namun demikian, untuk meningkatkan kegiatan produksi dan ekonomi masyarakat, selain kegiatan pertanian dan perkebunan juga perlu didukung dengan kegiatan ekonomi lain yang ramah lingkungan seperti ekowisata. Hal ini menjadi penting untuk mengurangi ketergantungan masyarakat terhadap perluasan lahan untuk pertanian yang terus meningkat dari tahun ke tahun. Suparno (2009) menjelaskan bahwa wilayah pesisir pada dasarnya tersusun dari berbagai macam ekosistem (mangrove, terumbu karang, estuari, pantai berpasir, dan lainnya) yang satu sama lain saling terkait, tidak berdiri sendiri. Perubahan/kerusakan yang menimpa satu ekosistem akan menimpa pula ekosistem lainnya. 


\section{Bentuk dan Penggunaan Lahan Wilayah Pesisir}

Hasil penelitian menunjukkan bahwa kecamatan yang terletak di wilayah pesisir untuk Kabupaten Katingan adalah Kecamatan Katingan Kuala dan Kecamatan Mendawai merupakan kecamatan yang terdapat di bagian paling selatan Kabupaten Katingan. Kecamatan Katingan Kuala mempunyai luas wilayah $1.440 \mathrm{~km}^{2}$, yang terdiri atas 10 desa/kelurahan, yaitu : 1) Pegatan Hilir; 2) Pegatan Hulu; 3) Kampung Keramat; 4) Kampung Tengah; 5) Kampung Baru; 6) Setia Mulia; 7) Bangun Jaya; 8) Jaya Makmur; 9) Subur Indah; dan 10) Singgam Raya. Kawasan pesisir ini memiliki panjang pantai \pm $54 \mathrm{~km}$ dan luas perairan laut $\pm 21.000 \mathrm{~km}^{2}$ serta kawasan hutan mangrove seluas \pm 17.000 ha. Kecamatan Mendawai mempunyai luas wilayah $1.826 \mathrm{~km}^{2}$, terdiri atas $7 \mathrm{desa} /$ kelurahan, yaitu : 1) Teluk Sebulu; 2) Mendawai; 3) Mekar Tani; 4) Kampung Melayu; 5) Tewang Kampung; 6) Perigi; dan 7)Tumbang Bulan. Kondisi panjang pantai, luas perairan laut, dan memiliki hutan mangrove merupakan potensi yang besar untuk dikembangkan sebagai daerah tujuan wisata yang berbasis konservasi. Namun demikian, wilayah pesisir merupakan wilayah yang sensitif dan kompleks dan ini merupakan kombinasi dua wilayah yang berbeda (Mihoubi et al., 2014).

Berdasarkan data statistik Kecamatan Katingan Kuala dalam Angka tahun 2006, secara fisiografis Kecamatan Katingan Kuala terdiri atas 5 bentuk lahan, yaitu (1) endapan pantai seluas 32.740 ha, (2) endapan sungai seluas 119.690 ha, (3) dome gambut seluas 239.890 ha, (4) dataran rendah batuan endapan pantai seluas 16.040 ha, dan (5) perbukitan intrusi masam seluas 16.280 ha. Dengan demikian, sekitar $80 \%$ wilayah Kecamatan Katingan Kuala terdiri atas wilayah fisiografi endapan sungai dan dome gambut (Gambar 2). Berdasarkan aspek penggunaannya, luas lahan basah di Kecamatan Katingan Kuala adalah 6.943 ha yang terbesar di 10 desa, sedangkan lahan kering di Kecamatan Katingan Kuala adalah seluas 65.251 ha yang tersebar di masing-masing desa. Lahan kering ini digunakan untuk berbagai kegiatan, di antaranya bangunan dan lahan pekarangan, kebun/tegalan, tambak, empang/kolam, tanah yang sementara tidak diusahakan, hutan rakyat, perkebunan, hutan negara, dan hutan lainnya. Luas lahan kering dimanfaatkan untuk areal persawahan, pertambakan, hutan, dan perkebunan tersebar di Desa Pegatan Hilir seluas 26.674 ha, di Desa Pegatan

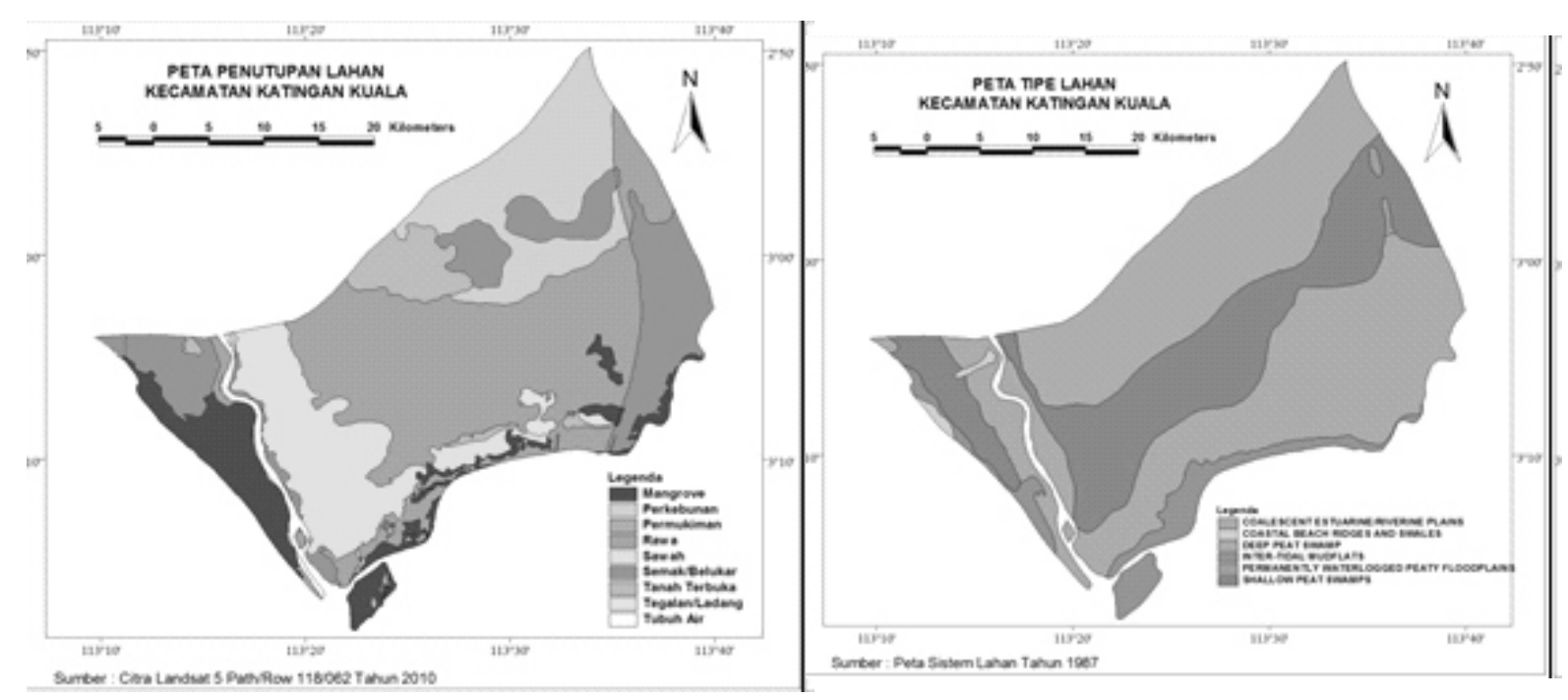

Gambar 2. Peta tipe lahan dan peta penutupan lahan Kecamatan Katingan Kuala 
Hulu seluas 17.558 ha, di Desa Kampung Keramat seluas 11.752 ha, dan di Desa Kampung Tengah seluas 9.267 ha.

Pengembangan kepariwisataan pada suatu kawasan dengan kondisi fisiografis seperti ini tidak dapat lepas dari peran serta masyarakat lokal dalam pengembangannya. Oleh karena itu, kesiapan dan kesadaran masyarakat dalam menyambut ekowisata di kawasan pesisir ini harus segera dilakukan. Peran serta masyarakat lokal pada kawasan ekowisata pesisir tidak hanya sebatas dalam penjualan makanan dan minuman. Hubungan kemitraan dengan industri pariwisata setempat harus terjalin. Bentuk kerjasama dengan masyarakat setempat untuk melakukan pengawasan dan pencegahan dalam mengendalikan lingkungan dan konservasi pesisir harus menjadi prinsip utama.

\section{Ekosistem Wilayah Pesisir}

Hasil penelitian menunjukkan bahwa ekosistem pesisir di Kecamatan Katingan Kuala terdiri atas sub-sistem mangrove, padang lamun, dan estuaria.

\section{Mangrove}

Ekosistem mangrove pada pada lokasi penelitian dapat dibedakan dalam tiga tipe utama, yaitu bentuk pantai/delta, bentuk muara sungai/laguna, dan bentuk pulau. Ketiga tipe tersebut terwakili pada ekosistem perairan pesisir. Berdasarkan hasil observasi dan wawancara dengan masyarakat setempat diketahui bahwa kawasan mangrove mempunyai fauna yang kaya akan udang-udangan yang besar, juga sebagai daerah asuhan (nursery ground), daerah mencari makanan (feeding ground), dan daerah pemijahan (spawning ground) bagi udang dan banyak jenis ikan pelagis yang bemilai komersial penting serta bermacam biota perairan lainnya baik yang hidup di perairan pantai maupun lepas pantai. Jenis hutan mangrove yang terdapat di kawasan pesisir Kalimantan Tengah pada umumnya dan Kabupaten Katingan khususnya sebagaimana disajikan pada Tabel 2.

Tabel 2 menunjukkan bahwa jenis hutan mangrove tersebut adalah jenis-jenis yang tumbuh di kawasan pesisir Kabupaten Katingan, terutama di daerah Pulau Damar dan Bajungkal. Potensi flora dan fauna hutan mangrove yang masih baik dan alamiah tentu sangat menarik jika dikembangkan sebagai daerah tujuan ekowisata baik yang bersifat lokal, nasional, maupun internasional. Persoalan mendasar yang dihadapi untuk mengembangkan

Tabel 2. Jenis hutan mangrove di lokasi penelitian

\begin{tabular}{ll}
\hline \multicolumn{1}{c}{ Suku } & \multicolumn{1}{c}{ Jenis } \\
\hline Avicenniaceae & Avicennia alba \\
Cimbretaceae & Lumnitzera littorea \\
Euphorbiaceae & Excoecaria agallocha \\
Flacoutiaceae & Scolopia macrophylla \\
Meliaceae & Xylocharpus grantum \\
Myrsinaceae & Aegiceras corniculatum \\
Mystaceae & Osbornia octodonta \\
Palmae & Nypa fruticans \\
Rhizophoraceae & Rhizophora apiculata \\
& Rhizophora mucronata \\
Sonnerataceae & Rhizophora stylosa \\
& Sonneratia alba \\
& Sonneratia caseolaris \\
\hline
\end{tabular}

Sumber: hasil survei lapangan tahun 2014 
potensi ini adalah terbatasnya akses transportasi untuk menuju kawasan tersebut. Sukarna dan Syahid (2015) menjelaskan bahwa perubahan yang terjadi pada hutan mangrove relatif cepat terjadi dan perubahan tersebut meliputi perubahan struktur, komposisi, dan keragaman vegetasinya.

\section{Padang lamun (seagrass)}

Hasil penelitian menunjukkan bahwa padang lamun tersebar di sepanjang perairan pantai, didominasi oleh lamun (tumbuhan laut yang berbunga (Angiospermae) yang memiliki rhizoma, daun, dan akar sejati yang hidup terendam di dalam laut) walaupun di antara tumbuhan ini ditemukan juga ganggang laut (sea weeds), termasuk ganggang hijau (green algae). Jenis lamun yang ditemukan di kawasan pesisir Kabupaten Katingan, yaitu (1) suku Potamogetonaceae dengan jenis : a) Halodule uninervis, b) Halodule pinifolia; dan c) Cymodoceae rotundata. Suku Hydrocharitaceae dengan jenis : a) Enhalus acoroides; b) Thalassia hemprichii; Hydrocharitaceae decipiens; d) Hydrocharitaceae spnulosa, dan e) Hydrocharitaceae beccarrii. Hasil penelitian ini tidak jauh berbeda dengan hasil penelitian MacKinnon et al., (2000). Banyak ikan dan invertebrata yang berkembang di padang lamun, seperti jenis ikan baronang, ikan biji nangka emas, belanak, kepiting, udang, kerang, dan teripang merupakan potensi yang besar untuk dikembangkan sebagai daerah ekowisata karena padang lamun juga merupakan tempat penangkapan ikan yang populer karena terdapat di pantai yang mudah dicapai.

\section{Estuaria}

Hasil penelitian menunjukkan bahwa kawasan ini termasuk dalam tipe lahan coalescent estuarine atau daerah riverine plans, yaitu daerah literal yang agak tertutup (teluk) di pantai, tempat sungai bermuara dan air tawar dari sungai bercampur dengan air asin dari laut dan biasanya berkaitan dengan pertemuan perairan sungai dengan air laut. Hasil observasi menunjukkan bahwa potensi produktivitas alami estuaria mampu menunjang aspek ekonomi daerah. Potensi ini harus dapat dikelola dan dimanfaatkan menjadi kawasan produksi maupun sebagai kawasan perlindungan. Sungai-sungai secara terus menerus membawa endapan, mineral, dan zat-zat hara ke dalam estuaria, memperbaharui bahan-bahan yang hilang untuk memelihara produktivitas yang tinggi. Produktivitas yang tinggi ini menjadikan zona estuaria sebagai sumber zat hara untuk perikanan komersial yang kaya baik di dekat pantai maupun jauh ke laut.

Secara umum zona estuaria pada lokasi penelitian mempunyai peranan ekologis penting terutama sebagai sumber zat hara dan bahan organik yang diangkut lewat sirkulasi pasang surut, penyedia habitat bagi sejumlah spesies hewan (ikan dan udang) yang bergantung pada estuaria sebagai tempat berlindung dan tempat mencari makanan (feeding ground), dan sebagai tempat untuk berproduksi serta tempat tumbuh besar (nursery ground) terutama bagi sejumlah spesies ikan dan udang.

\section{Zonasi Ekologi Bentang Lahan Kawasan Pesisir}

Penetapan zonasi kawasan adalah pengelompokan areal suatu kawasan ke dalam zona-zona sesuai dengan kondisi biofisik dan fungsinya. Tujuan penentuan zonasi adalah untuk mengoptimalkan fungsi ekologi dan ekonomi ekosistem suatu kawasan sehingga dapat dilakukan pengelolaan pemanfaatan kawasan secara berkelanjutan. Berdasarkan kondisi wilayah pesisir dan potensi sumberdaya alam yang ada di Kecamatan Katingan Kuala, dilakukan analisis Sistem Informasi Geografi (SIG). Hasil análisis zonasi bentang lahan lokasi penelitian pada Tabel 3 menunjukkan bahwa secara 
umum pembagian zonasi dapat dilakukan menjadi tiga zona, yaitu zona inti untuk konservasi, rehabilitasi dan perlindungan; zona budidaya untuk pemanfaatan ekonomi dan produksi masyarakat; dan zona penyangga sumberdaya alam untuk pemanfaatan secara terbatas seperti ekowisata.

Hasil penelitian menunjukkan bahwa kawasan konservasi daerah pesisir Kecamatan Katingan Kuala umumnya didominasi oleh kawasan lahan basah seperti hutan mangrove dan hutan rawa gambut. Hasil zonasi ekologi bentang lahan memperlihatkan bahwa pada kawasan mangrove umumnya dapat dikembangkan sebagai zona ekowisata dan bagian yang bergambut dalam dapat dijadikan zona konservasi. Hal ini sesuai dengan penjelasan Kathiresan (2012) bahwa hutan mangrove merupakan sumberdaya pesisir yang sangat penting dan vital untuk kehidupan sosial dan ekonomi masyarakatnya.

Zonasi hutan mangrove di lokasi penelitian terdiri dari Avicennia spp., pada daerah yang paling dekat dengan laut, dengan substrat agak berpasir. Pada zona ini berasosiasi Sonneratia spp. yang dominan tumbuh pada lumpur dalam yang kaya bahan organik. Lebih ke arah darat, hutan mangrove umumnya didominasi oleh Rhizophora spp. Di zona ini juga dijumpai Bruguiera spp. dan Xylocarpus spp. Zona berikutnya didominasi oleh Bruguiera spp. Terakhir pada zona transisi antara hutan mangrove dengan hutan dataran rendah biasanya ditumbuhi oleh Nypa fruticans, dan beberapa spesies palem lainnya. Perlindungan terhadap hutan mangrove adalah dengan menetapkan kawasan tersebut sebagai zona konservasi dan sebagai zona ekowisata di sepanjang pantai dan tepi sungai. Putra (2014) menjelaskan bahwa kawasan ekowisata mangrove dapat dibagi ke dalam 3 zona kawasan, yaitu zona penerima yang berfungsi sebagai area pusat informasi, area komersial, dan pengelola kawasan ekowisata, dan zona buffer dan core yang berfungsi sebagai area konservasi dan wisata alam.

Hasil penelitian lain menunjukkan bahwa hutan mangrove saat ini mengalami tekanan yang cukup tinggi dari berbagai aktifitas seperti tambak, pemukiman, dan pemanfaatan lainnya. FAO (2007). Giri dan Muhlhausen (2008) melaporkan bahwa antara tahun 1975 atau 1980 sampai tahun 2005 sekitar $25 \%$ wilayah mangrove di Asia Tenggara telah dikonversi menjadi berbagai macam penggunaan lahan. Laju kerusakan ekosistem hutan mangrove lebih besar dibandingkan dengan laju pelestarian ekosistem hutan mangrove padahal mangrove sangat rentan terhadap perubahan iklim dan penggunaan lahan (Murdiyarso et al., 2009).

Tabel 3. Matrik zonasi ekologi bentang lahan pada lokasi penelitian

\begin{tabular}{lllll}
\hline $\begin{array}{c}\text { Penggunaan/Penutupan } \\
\text { Lahan (Land Usel } \\
\text { Land Cover) }\end{array}$ & Gambut Dalam & Gambut Dangkal & $\begin{array}{c}\text { Estuari/Dataran } \\
\text { Sungai }\end{array}$ & $\begin{array}{c}\text { Garis Pantai/ } \\
\text { Padang Lamun }\end{array}$ \\
\cline { 2 - 5 } & Zona konservasi & Zona penyangga & Zona ekowisata & Zona penyangga \\
\hline Rawa & Zona rehabilitasi & Zona rehabilitasi & Zona rehabilitasi & Zona produksi \\
\hline Lahan terbuka & Zona rehabilitasi & Zona rehabilitasi & Zona produksi & Zona penyangga \\
\hline Perkebunan & Zona rehabilitasi & Zona produksi & Zona produksi & Zona penyangga \\
\hline Sawah & Zona rehabilitasi & Zona produksi & Zona produksi & Zona penyangga \\
\hline Tegalan/ Ladang & Zona konservasi & Zona rehabilitasi & Zona rehabilitasi & Zona ekowisata \\
\hline Semak/ Belukar & Zona rehabilitasi & Zona produksi & Zona produksi & Zona produksi \\
\hline Tambak & Zona konservasi & Zona ekowisata & Zona ekowisata & Zona ekowisata \\
\hline Hutan Mangrove & Zona rehabilitasi & Zona produksi & Zona produksi & Zona ekowisata \\
\hline Pemukiman & & & &
\end{tabular}

Sumber: hasil análisis data spasial tahun 2014 
Bengen (2001) menjelaskan bahwa hutan mangrove berfungsi sebagai peredam gelombang dan angin badai, pelindung dari abrasi, penahan lumpur, dan perangkap sedimen, penghasil sejumlah detritus dari daun dan dahan pohon mangrove, daerah asuhan (nursery grounds), mencari makan (feeding grounds), dan pemijahan (spawning grounds) berbagai jenis ikan, udang, dan biota laut lainnya, penghasil kayu untuk konstruksi, kayu bakar, bahan baku arang, dan bahan baku kertas (pulp), pemasok larva ikan, udang dan biota lainnya, dan tempat pariwisata.

Zona ekowisata yang juga dapat dikembangkan pada ekosistem yang lain seperti ekosistem hutan rawa pada estuaria atau dataran sungai, kawasan belukar pada estuaria atau dataran sungai, dan kawasan pemukiman yang berada pada garis pantai atau padang lamun. Zonasi ekologi bentang lahan pada lokasi penelitian secara garis besar dapat dikelompokkan seperti pada Tabel 4.

Hasil analisis spasial ekologi bentang lahan wilayah pesisir Kecamatan Katingan Kuala dapat dilihat pada Gambar 3.
Proses pembangunan dan pengelolaan sumber daya pesisir dan laut di Kecamatan Katingan Kuala sebaiknya dimulai dengan perencanaan yang mencakup dasar-dasar pemikiran, sumberdaya yang digunakan, sasaran dan tujuan ditetapkan dalam tahap perencanaan yang kemudian dilanjutkan dengan pelaksanaan, pengawasan, dan evaluasi. Hal yang mendasar adalah bahwa potensi ekowisata pada kawasan pesisir Kecamatan Katingan Kuala secara umum belum mampu ditangkap sebagai peluang oleh masyarakat setempat. Peluang masyarakat lokal dalam memperoleh tambahan ataupun peningkatan pendapatan diperoleh melalui cenderamata, menyediakan jasa angkutan, dan sebagainya. Pemanfaatan dan optimalisasi pengetahuan tradisional yang berbasis pelestarian alam dan budaya serta nilai-nilai yang terkandung dalam kehidupan masyarakat sehari-hari perlu dimunculkan dalam pengembangan zona ekowisata. Hal-hal yang mendukung dalam pengembangan kawasan ekowisata di Kecamatan Katingan Kuala antara lain :

1. Keindahan alam yang masih natural, namun harus diimbangi dengan upaya menjaga lingkungan konservasi alam.

Tabel 4. Hasil analisis alokasi zonasi ekowisata pada lokasi penelitian

\begin{tabular}{|c|c|c|c|c|}
\hline No. & $\begin{array}{c}\text { Pengembangan } \\
\text { Kawasan }\end{array}$ & $\begin{array}{l}\text { Target Pemanfaatan } \\
\text { Pengembangan }\end{array}$ & Lokasi & $\begin{array}{l}\text { Alokasi Zona dari } \\
\text { Luas Total } \\
\text { Kecamatan }\end{array}$ \\
\hline 1 & $\begin{array}{l}\text { Kawasan Penyangga } \\
\text { dan zona ekowisata }\end{array}$ & $\begin{array}{l}\text { Sempada pantai, muara dan laut, } \\
\text { daerah terbuka, pemukiman dan } \\
\text { sebagian hutan mangrove }\end{array}$ & $\begin{array}{l}\text { Selat Baning, Pesisir } \\
\text { Selat, Pulau Damar } \\
\text { Muara Sebangau dan } \\
\text { pemukiman }\end{array}$ & $47,13 \%$ \\
\hline 2 & $\begin{array}{l}\text { Kawasan inti untuk } \\
\text { Konservasi dan } \\
\text { rehabilitasi keragaman } \\
\text { alami dan serapan } \\
\text { karbon }\end{array}$ & $\begin{array}{l}\text { Hutan mangrove dan hutan rawa } \\
\text { gambut, Sempada pantai }\end{array}$ & $\begin{array}{l}\text { Pulau Burung, Jeruju } \\
\text { Kearah Timur, Taman } \\
\text { Nasional }\end{array}$ & $29,55 \%$ \\
\hline 3 & $\begin{array}{l}\text { Kawasan untuk } \\
\text { pengembangan } \\
\text { ekonomi/ produksi } \\
\text { secara terbatas }\end{array}$ & $\begin{array}{l}\text { Sempada pantai, semak belukar, } \\
\text { sawah, daerah terbuka, dan } \\
\text { perkebunan }\end{array}$ & $\begin{array}{l}\text { Pesisir Selat, Muara } \\
\text { Sebangau, Selat Baning } \\
\text { dan pemukiman }\end{array}$ & $23,31 \%$ \\
\hline
\end{tabular}

Sumber: hasil analisis spasial dan survei lapangan tahun 2014 


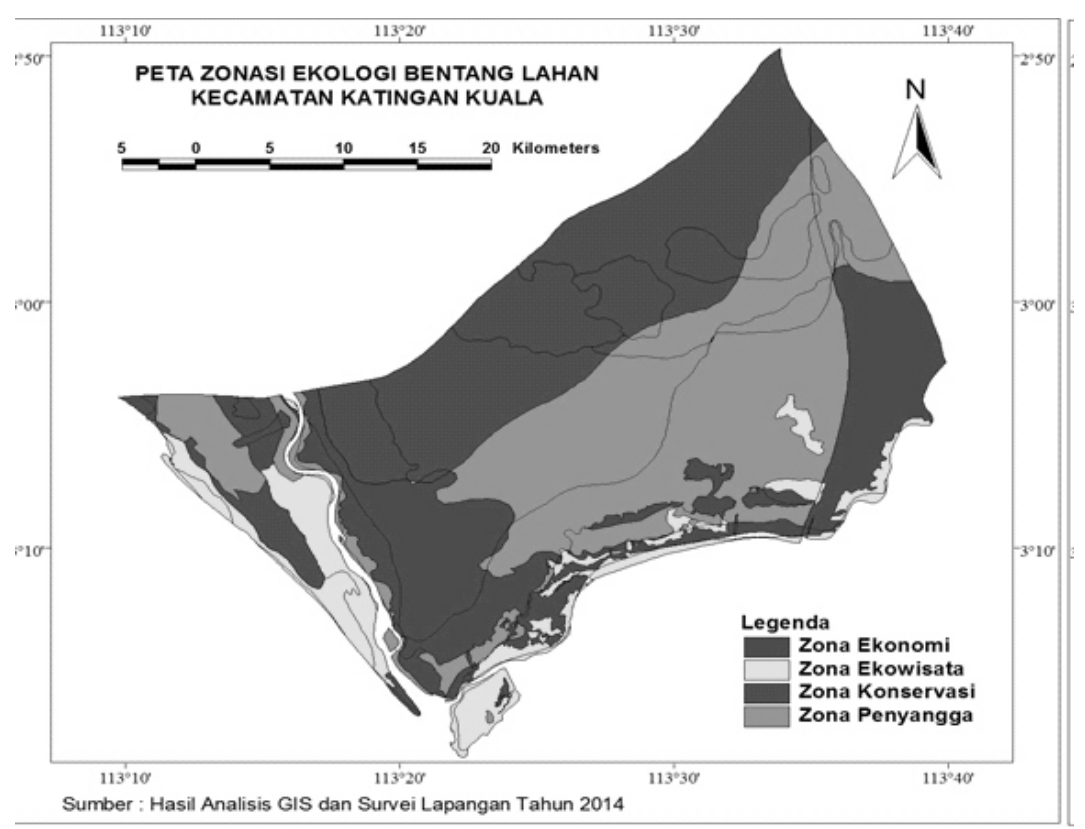

Gambar 3. Zonasi ekologi bentang lahan Kecamatan Katingan Kuala

2. Fasilitas pendukung kepariwisataan seperti pusat informasi, fasilitas akomodasi penginapan, fasilitas makan dan minum sudah cukup memadai.

3. Diversifikasi kesenian dan budaya lokal dapat diandalkan dalam mendukung ekowisata di wilayah ini.

\section{KESIMPULAN}

Hasil penelitian menyimpulkan bahwa zonasi ekologi bentang lahan wilayah pesisir Kecamatan Katingan Kuala, Kabupaten Katingan, Provinsi Kalimantan Tengah dapat dikembangkan menjadi zona ekowisata $\pm 15,83 \%$, zona penyangga sebagai penunjang ekowisata $\pm 31,30 \%$, zona inti untuk konservasi dan rehabilitasi $\pm 29,55 \%$, dan zona produksi dan ekonomi $\pm 23,31 \%$. Proporsi zonasi ini menjelaskan bahwa kegiatan pariwisata di wilayah pesisir harus serasi dan selaras dengan upaya pelestarian dan menjaga fungsi lindungnya dalam rangka pelestarian lingkungan hidup. Kawasan konservasi untuk keragaman alami dimaksudkan untuk melindungi ekosistem pesisir dari berbagai fungsi perubahan lahan. Kawasan untuk zona perlindungan tata air dan serapan karbon diprioritaskan adalah hutan rawa gambut.

Pembagian tiga zona kelola tersebut lebih dimaksudkan sebagai suatu kawasan yang mencakup beragam flora dan fauna yang memiliki nilai ekologis, ekonomis, sosial, dan budaya secara berimbang. Penetapan zona ekowisata di wilayah pesisir harus mampu melindungi habitat-habitat kritis, mempertahankan keanekaragaman hayati, mengkonservasi sumberdaya alam, melindungi garis pantai, melindungi lokasi-lokasi yang bernilai sejarah dan budaya, dan mempromosikan pembangunan pesisir dan kelautan yang berkelanjutan.

\section{UCAPAN TERIMA KASIH}

Ucapan terima kasih disampaikan kepada Badan Lingkungan Hidup Daerah Kabupaten Katingan Provinsi Kalimantan Tengah yang telah memberikan bantuan biaya untuk melakukan kajian dan penelitian kawasan konservasi wilayah pesisir di Kecamatan Katingan Kuala Tahun 2014. 


\section{DAFTAR PUSTAKA}

Bengen DG. 2001. Sinopsis Ekosistem dan Sumberdaya Alam Pesisir dan Laut. Cetakan Kedua. Pusat Kajian Sumberdaya Pesisir dan Laut. Institut Pertanian Bogor. Bogor.

BPS Kabupaten Katingan. 2013. Katingan dalam Angka Tahun 2013.

BPS Kabupaten Kotawaringin Timur. 2006. Kecamatan Katingan Kuala dalam Angka 2006. Kerjasama Badan Pusat Statistik (BPS) Kabupaten Kotawaringin Timur dengan Badan Perencanaan Pembangunan Daerah (BAPPEDA) Kabupaten Katingan Tahun 2006.

Dahuri R, Rais J, Ginting SP, \& Sitepu MJ. 1996. Pengelolaan Sumberdaya Wilayah Pesisir dan Lautan Secara Terpadu.Pradya Paramita. Jakarta.

Darmawijaya MI.1997. Klasifikasi Tanah Dasar. Teori bagi Peneliti Tanah dan Pelaksana Pertanian di Indonesia. Gadjah Mada University Press. Yogyakarta.

FAO (Food and Agriculture Organization of the United Nations), 2007. The world's mangroves 1980-2005. FAO Forestry Report 153. Rome.

Farina A. 1998. Principles and Methods in Landscape Ecology. Chapman \& Hall. London.

Forman RT \& Gordon M. 1986. Landscape Ecology. John Wiley and Son. New York.

Giri C \& Muhlhausen J. 2008. Mangrove forest distributions and dynamics in Madagascar (1975-2005). Sensors 8, 2104-2117.

Kathiresan K. 2012. Importance of mangrove ecosystem. International Journal of Marine Science 2 (10), 70-89.

Mackinnon K, Hatta G, Halim H, \& Mangalik A. 2000. The Ecology of Kalimantan.Terjemahan. Prenhallindo, Jakarta.

Mihoubi MK, Belkessa R \& Latreche MA. 2014. Study of the vulnerability of coastal areas of the Algerian Basin with the GIS. International Journal of Environmental Science and Development 5(6), 522-526.

Murdiyarso D, Donato D, Kauffman JB, Kurnianto S, Stidham M, \& Kanninen M. 2009. Carbon Storage in Mangrove and Peatland Ecosystems: A Preliminary Account from Plots in Indonesia. Working paper 48, Center for International Forestry Research (CIFOR) Bogor, Indonesia. 35.

Nybakken JW. 1989. Marine Biology: An Ecological Approach. Harper and Row Publisher, New York.
Pemerintah Daerah Propinsi Kalimantan Tengah, 2003. Rencana Strategis Pengelolaan Laut Propinsi Kalimantan Tengah Tahun 2003-2005. Palangka Raya.

Peraturan Menteri Kelautan dan Perikanan Republik Indonesia Nomor 17 Tahun 2008 Tentang Kawasan Konservasi di Wilayah Pesisir dan Pulau Pulau Kecil di Indonesia.

Priono Y. 2012. Pengembangan kawasan ekowisata Bukit Tangkiling berbasis masyarakat. Jurnal Perspektif Arsitektur 7 (1), 51-67.

Putra W. 2014. Kawasan ekowisata hutan mangrove di Desa Kuala Karang Kabupaten Kubu Raya. Jurnal Arsitektur Universitas Tanjung Pura 2(2), 41-55.

Sukarna RM \& Syahid Y. 2015. FCD application of landsat for monitoring mangrove in Central Kalimantan. Indonesian Journal of Geography 47 (2), 160-170.

Suparno 2009. Zonasi wilayah pesisir dan pulau pulau kecil sebagai salah satu dokumen penting untuk disusun Pemerintah Daerah Provinsi/Kabupaten/Kota. Jurnal Mangrove dan Pesisir 11(1), 1-8.

Undang Undang Pemerintah Republik Indonesia No. 27 Tahun 2007 tentang Pengelolaan Wilayah Pesisir dan Pulau Pulau Kecil. Kementerian Hukum dan HAM, Jakarta.

Vink APA. 1983. Landscape Ecology and Land Use. Longman Inc. New York.

Young RH, Green DR, \& Cousins S. 1993. Landscape Ecology and Geographic Information System. Taylor and Francis, London.

Zonneveld IS. 2001. Landscape Ecology Applied in Land Evaluation, Development and Conservation. International Institute for Aerospace Survey and Earth Sciences ITC. 